\title{
腹部大動脈瘤の自然経過と手術適応
}

\author{
檜 原 淳* 古山正人竹尾貞徳池尻公二
}

\begin{abstract}
当科において過去 6 年 6 か月間に経験した腹部大動脈瘤症例のうち, 経過観察期間を有する 33 症例に ついて動脈瘤最大径の経時的変化を調査し,延べ 69 回の経過観察期間ごとに動脈瘤径拡大速度を算出 した. 弚の結果, 瘤径 $5 \mathrm{~cm}$ を境にして瘤径拡大速度は平均 $0.41 \mathrm{~cm} /$ 年から $1.38 \mathrm{~cm} /$ 年へと約 3 倍に 増加していた. 異状型動脈瘤は紡鍾型動脈瘤に比べて小さい瘤径でも拡大傾向が強く, 瘤径 $4 \mathrm{~cm}$ を境 にして拡大速度が 4 倍以上に増加していた。高血圧合併例は非合併例より拡大速度が遅く，年跉によ る瘤径拡大速度の差は認められなかった。緊急手術が必要とされる破裂性腹部大動脈瘤症例はいまだ に手術死亡率が高く, 治療成績を向上させるためには破裂前に手術を施行することが必要である.し たがって厳重な経過観察の上で, 瘤破裂の危険性が急速に増大する前, すなわち紡鍾型では瘤径 $5 \mathbf{c m}$ 以上, 霟状型では $4 \mathrm{~cm}$ 以上を手術適応とし，これに症例ごとのリスクを考虑に入れて手術時期を決定 するのが望ましいと思われる。 日心外会誌 25 巻 2 号 : 95-98（1996）
\end{abstract}

Keywords：腹部大動脈瘤, 手術適応, 動脈瘤径拡大速度

\section{Natural History of Abdominal Aortic Aneurysm and Indication for Surgical Repair}

Jun Hihara*, Masato Furuyama, Sadanori Takeo and Koji Ikejiri (Department of Surgery, National Hospital Kyushu Medical Center, Fukuoka, Japan and Department of Surgical Oncology, Research Institute for Radiation Biology and Medicine*, Hiroshima University, Hiroshima, Japan)

The natural course of abdominal aortic aneurysm was studied in 33 patients by measuring the diameter size of aneurysms by computed tomography during period of 3 to 36 months. The ratio of the increase in diameter of aneurysms was calculated at each period (total 69 periods). The expansive ratio which had a diameter of over $5 \mathrm{~cm}(1.38 \mathrm{~cm} /$ year $)$ exceeded that of under $5 \mathrm{~cm}$ $(0.41 \mathrm{~cm} /$ year $)$ by more than three times. Saccular aneurysms tended to expand more rapidly than fusiform aneurysms, and particularly this tendency was obvious in small size of aneurysms. The expansive ratio of patients with hypertention was lower than that of the patients without hypertension. The age of patients had no effect on the expansion ratio. Since operative mortality for ruptured abdominal aortic aneurysm is high, surgery before rupture is essential to reduce the mortality of abdominal aortic aneurysm. We decided that the patient should be operated when the aneurysms develop a diameter of $5 \mathrm{~cm}$ in cases of fusiform aneurysms and $4 \mathrm{~cm}$ in cases of saccular aneurysms. In addition it is necessary to consider age, possible complications and other conditions of each case in order to determine the timing of surgical repair. Jpn. J. Cardiovasc. Surg. 25 : 95-98 (1996)

\section{これまで当科では腹部大動脈瘤の手術適応を紡} 錘型は最大径 $5 \mathrm{~cm}$ 以上, 囊状型は最大径 $4 \mathrm{~cm}$ 以 上としてきた。今回，当科における過去 6 年半の 経過観察症例から腹部大動脈瘤の自然経過を観察 することにより，この手術適応について再検討し てみることとした。

1995 年 4 月 28 日受付, 1995 年 6 月 26 日採用

国立病院九州医療センター外科 $\bar{T} 810$ 福岡市中央区地行浜 1-8-1

* 現 広島大学原爆放射能医学研究所腫場外科

本論文の要旨は, 第 60 回九州血管外科愁話会 (1992 年 8 月, 唐 津)において発表した。
対 象

1985 年 10 月から 1992 年 3 月までの 6 年 6 か 月間に,国立福岡中央病院 (現：国立病院九州医療 センター)外科を受診した腹部大動脈瘤症例 69 例 を対象とした。内訳は男性 58 例，女性 11 例で， 年齢は 55 83 歳, 平均 69.8 歳であった。臨床経 過は (1) 経過観察することなく初診直後に手術を 施行したもの 30 例 (44.1\%)，(2) 経過観察ののち 手術を施行したもの 14 例(19.1\%), ( 3 ) 経過観察 のみで手術を施行しなかったもの 20 例(29.4\%), 
(4)初診以降来院せず follow up できなかったも の 5 例 (7.4\%)であった.

\section{方法}

経過観察を行った上記 ( 2 ), ( 3 ) の症例 33 例に つき, 腹部 CT 上での腹部大動脈瘤最大径の経時 的変化を調べ，さらに，各観察期間ごとの動脈瘤 径拡大速度を算出し, 動脈瘤径 $(5 \mathrm{~cm}$ 末満と $5 \mathrm{~cm}$ 以上)，動脈瘤の形状(囊状型と紡鍾型)，年齢 $(70$ 歳未満と 70 歳以上), 高血圧合併の有無 (合併あり と合併なし)の項目について動脈瘤拡大速度を比 較した. 動脈瘤径拡大速度 (cm/年) は, (経過観察 後の動脈瘤径 $[\mathrm{cm}]$ 一経過観察前の動脈瘤径 $[\mathrm{cm}]) /$ 経過観察期間 $[$ 月 $] \times 12$ の式に当てはめ算 出した.

なお， 2 回以上の観察期間を有する症例につい ては各観察期間を別個に扱い, 33 症例, 延べ 69 回 の観察期間について動脈瘤径拡大速度を算出し た。

\section{結 果}

\section{1. 腹部大動脈瘤最大径の経時的変化}

経過観察を行った 33 例の動脈瘤最大径の変化 を図 1 に示した。最大径が $4 \mathrm{~cm}$ を越えるあたり から瘤径の拡大寸る速度が速くなりはじめて，5 $\mathrm{cm}$ を越えると急速に拡大する傾向が認められ た。

\section{2. 動脈瘤径と瘤径拡大速度}

延べ 69 回の経過観察期間ごとに,動脈瘤径とそ の後の瘤径拡大速度の分布を図 2 に示した。全体

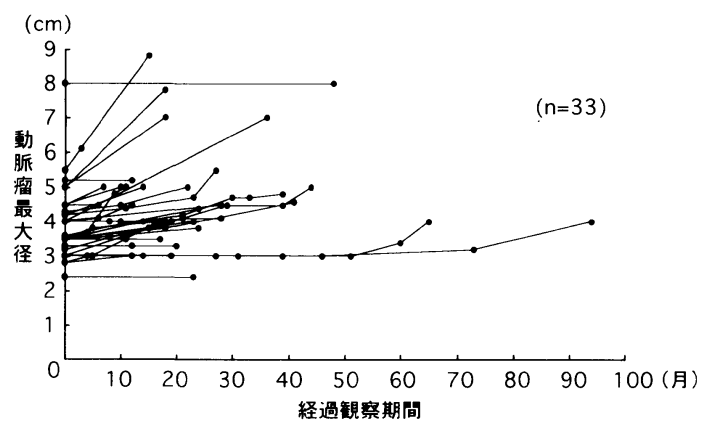

図 1 経過観察期間中の腹部大動脈溜最大径の変化 $n=33$.
として, 動脈瘤径が大きくなるほど瘤径拡大速度 が増加する傾向が認められる。

表 1 には動脈瘤最大径とその後の瘤径拡大速度 の平均值を示した。動脈瘤径 $5 \mathrm{~cm}$ を境にして瘤 径拡大速度は $0.46 \mathrm{~cm} /$ 年 (瘤径 $4 \sim 5 \mathrm{~cm}$ ) から $1.40 \mathrm{~cm} /$ 年(瘤径 5 6 cm) へと約 3 倍に増加し ていた。さらに動脈瘤径が $5 \mathrm{~cm}$ 末満の群と $5 \mathrm{~cm}$ 以上の群とにまとめて瘤径拡大速度を比較したと ころ, $5 \mathrm{~cm}$ 未満の群では瘤径拡大速度が平均 $0.41 \mathrm{~cm} /$ 年であったのに対し, $5 \mathrm{~cm}$ 以上の群で は $1.38 \mathrm{~cm} /$ 年と 3.4 倍に増加し, 両者の間には有 意差が認められた $(p<0.01)$.

\section{3. 動脈瘤の形状と瘤径拡大速度}

動脈瘤の形状により紡鍾型の群 $(n=49$, 平均 $0.41 \mathrm{~cm} /$ 年) と囊状型の群 $(n=20$, 平均 $0.70 \mathrm{~cm} /$ 年)の間で瘤径拡大速度を比較した (図 3 ).紡鍾型 より囊状型のほうが拡大速度がやや大きい結果を 得たが，両者の間に有意差は認められなかった。

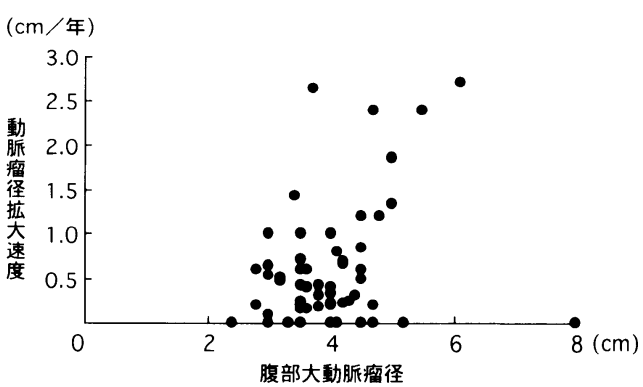

図 2 腹部大動脈瘤径と瘤径拡大速度 $n=69$.

表 1 腹部大動脈瘤最大径と瘤径拡大速度

\begin{tabular}{|c|c|c|}
\hline $\begin{array}{c}\text { 腹部大動脈瘤最大径 } \\
(\mathrm{cm})\end{array}$ & $n$ & $\begin{array}{c}\text { 平均瘤径拡大速度 } \\
(\mathrm{cm} / \text { 年 })\end{array}$ \\
\hline$\sim 2.9$ & 3 & 0.27 \\
\hline $3.0 \sim 3.9$ & 34 & 0.37 \\
\hline $4.0 \sim 4.9$ & 26 & $0.46^{-}$ \\
\hline $5.0 \sim 5.9$ & 4 & 1.40 \\
\hline $6.0 \sim$ & 2 & 1.35 \\
\hline 計 & 69 & 0.49 \\
\hline
\end{tabular}

$* p<0.01$ 


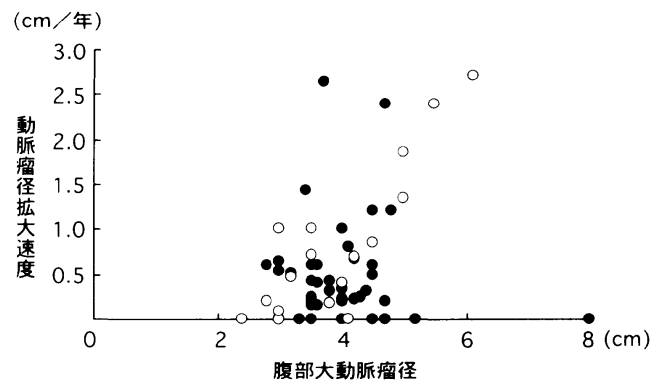

図 3 動脈瘤の形状と瘤径抎大速度

○紡錘型 $(n=49), \bigcirc$ 㗆状型 $(n=20)$.

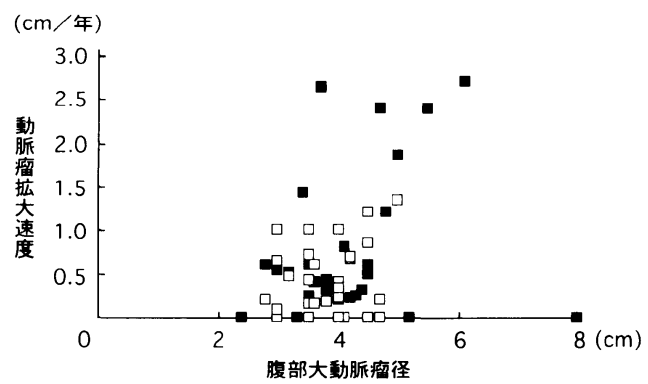

図 4 年齢と瘤径拡大速度

70 歳以上 $(n=35), \square 70$ 歳末満 $(n=34)$.

\section{4. 年齢と瘤径拡大速度}

年齢が 70 歳未満の症例 $(n=34$, 平均 $0.37 \mathrm{~cm} /$ 年) と 70 歳以上の症例 $(n=35$, 平均 $0.61 \mathrm{~cm} /$ 年 $)$ を比較したところ(図 4), 70 歳以上の)症例がより 大きい拡大速度を示したが, 両者の間に有意差は 認められなかった。

\section{5. 高血圧合併の有無と瘤径拡大速度}

高血圧を合併した症例 $(n=30$, 平均 $0.24 \mathrm{~cm} /$ 年) と合併しない症例 $(n=39$, 平均 $0.59 \mathrm{~cm} /$ 年) との比較では (図 5 ), 高血圧非合併例は合併例よ りも有意に平均拡大速度が速いという結果になっ た $(p<0.05)$.

\section{6. 囊状型腹部大動脈瘤における動脈瘤径と瘤 径拡大速度}

これまでの経験より，囊状型は紡錘型に比して 瘤径が小さくてもより破裂の危険性が高いと思わ れるため, 霊状型腹部大動脈瘤症例だけに限り動 脈瘤径と瘤径拡大速度を検討した。瘤径 $5 \mathrm{~cm}$ 末 満の群 $(n=16$, 平均 $0.35 \mathrm{~cm} /$ 年) と $5 \mathrm{~cm}$ 以上の 群 $(n=4$, 平均 $2.08 \mathrm{~cm} /$ 年) とに分け両者を比較

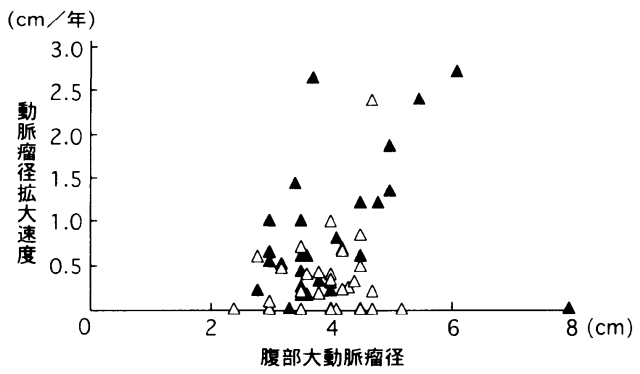

図 5 高血圧合併の有無と瘤径拡大速度 $\Delta$ 高血圧 $(-)(n=39), \triangle$ 高血圧 $(+)(n=30)$.

したところ有意差が認められた $(p<0.01)$.また， 瘤径 $4 \mathrm{~cm}$ 末満の群 $(n=12$, 平均 $0.30 \mathrm{~cm} /$ 年 $)$ と 4 $\mathrm{cm}$ 以上の群 $(n=8$, 平均 $1.28 \mathrm{~cm} /$ 年)に分けて も, 両者の間に有意差が認められた $(p<0.01)$.

\section{考察}

Laplace の法則では，動脈瘤径の挔大とともに 動脈瘤壁に加わる張力は増大し，それに伴って瘤 径拡大も速くなり瘤破裂の危険が高くなるとされ ている(1).今回の結果でも, 一部の例外を除き, 瘤 径が大きくなるにつれて瘤径拡大速度も加速度的 に増大する傾向が認められ, 瘤径 $5 \mathrm{~cm}$ を境にし て約 3 倍に増加していた。囊状型動脈瘤だけに限 っていえば, 瘤径 $4 \mathrm{~cm}$ を超えると瘤径拡大速度 が急激に増大して抢り，紡鍾型に比べ小さい瘤径 でも瘤径拡大速度が増加すると思われる。

腹部大動脈瘤の主な増悪因子の一つである高血 圧合併の有無による瘤径拡大速度の比較では, 意 外にも高血圧合併例のほうが拡大速度が遅いとい う結果であった，理由ははっきりとしないが，高 血圧合併例はほとんどの症例で降圧剤などで血圧 がコントロールされており，あるいはこのことが 関係しているのかもしれない。一方，年齢による 瘤径拡大速度の差は認められなかった。

今日，血管外科の手術手技および周術期管理の 進歩に伴い, 腹部大動脈瘤待機手術症例の手術死 亡率は $5 \%$ 前後と治療成績はほぼ安定したものと なっている2). しかし, 緊急手術が必要とされる破 裂性腹部大動脈瘤症例では, いまだに手術死亡率 が 30〜 40\%と高く ${ }^{2)}$, 治療成績を向上させるため には，当然早期診断を行い破裂前に手術を行わな 
ければならない. Szilagyi らは, 瘤径が $4 \mathrm{~cm}$ 末満 であっても 5 年以内に $15 \%$ の瘤が破裂し, 径が 6 $\mathrm{cm}$ になると破裂の危険度は $30 \%$ に増大し, さら に $8 \mathrm{~cm}$ 以上であれば $75 \%$ を超えるとしており， しかも, 瘤径が $6 \mathrm{~cm}$ を超えると瘤径は急速に増 大し, 径 $6 \mathrm{~cm}$ を境にして非手術例と手術例との 間で生存曲線に有意差を認めると報告してい $ろ^{1,3)}$.

われわれは，手術の絶対的適応となる感染性動 脈瘤あるいは炎症性動脈瘤を除き, 紡鍾型は最大 径 $5 \mathrm{~cm}$ 以上, 霊状型は最大径 $4 \mathrm{~cm}$ 以上を手術適 応としてきた. 囊状型の手術適応を径 $4 \mathrm{~cm}$ 以上 としたのは, 径 $4 \mathrm{~cm}$ の囊状型動脈瘤の破裂経験 があり, 経験的に径 $4 \mathrm{~cm}$ を超えると急速に瘤径 が拡大すると感じられたからである.今回の結果 と照らし合わせてみると, 従来の当科の手術適応 は瘤破裂の危険性が急速に増大する前に手術を施 行するという意味で，ほぼ妥当なものであったと いえる。

破裂を予知する確実な指標がない現在, 腹部大 動脈瘤を発見し次第手術をすることが望ましいと いう考え方にも一理あるが, 一方では, 緩徐に増 大するものや長年にわたって増大も破裂も示さな い腹部大動脈瘤が存在することも事実であり ${ }^{4)}$, 無症状のまま経過し他病にて死亡する例が腹部大 動脈瘤症例のうち $50 \%$ 近くもあるという ${ }^{1)}$. 実際, われわれも 5 年以上瘤径 $3 \mathrm{~cm}$ のまま増大しなか つた症例や， 4 年間瘤径 $8 \mathrm{~cm}$ のまま増大も破裂 もしなかった症例を経験している.

したがって実際の臨床現場においては, 従来の 手術適応(紡鍾型は最大径 $5 \mathrm{~cm}$ 以上, 囊状型は最
大径 $4 \mathrm{~cm}$ 以上) を基本として, 若年者や手術によ る危険が少ないと思われる症例ではやや早めに瘤 径 $4 \mathrm{~cm}$ 程度で手術を選択し，リスクの高い症例 では瘤径 $5 \mathrm{~cm}$ までは経過を観察し, 明らかに増 大傾向のある場合は手術を施行するのが妥当と思 われる ${ }^{1,2,5)}$. 高歯者でも他の危険因子が悪くなけ れば原則として手術を選択すべきであると考え る. 手術を施行しない例については，3〜6か月 程度の間隔でできるだけ頻繁に CT, エコーで経 過観察を行い, 動脈瘤による疼痛や圧迫症状など の発現, 瘤径拡大速度の急激な増加などが認めら れれば瘤径にかかわらず手術を考慮するのが適当 であると思われる ${ }^{6)}$.

\section{文献}

1）富川正樹, 上山武史, 笠島 学ほか：腹部大動脈 瘤 19 例の自然予後. 現代医療 20:3343-3347, 1988.

2) 安田慶秀, 田辺達三: 手術適応と手術の夕イミン グ “腹部大動脈瘤”。診断と治療 73: 1239-1241, 1985.

3) Szilagyi, D. E., Smith, R. F., DeRusso, F. J. et al.: Contribution of abdominal aortic aneurysmectomy to prolongation of life. Ann. Surg. 164: 678-699, 1966.

4）塩野谷恵彦：“診断と治療上の特異点と術式” 非 破裂性腹部大動脈瘤。外科 MOOK No. 50 , 金原 出版, 東京, 1988, pp. 193-198.

5）安田慶秀：動脈硬化性大動脈瘤外科的治療一腹 部大動脈瘤。現代医療 23：2098-2101，1991.

6）増田善昭, 高須準一郎, 高梨一紀：動脈硬化性大 動脈瘤内科的治療一自然経過と破裂の予測, 予 防, 外科治療を依頼する夕イミング。現代医療 23 : 2085-2089, 1991. 